\title{
Methane-oxidizing and photoautotrophic bacteria are major producers in a humic lake with a large anoxic hypolimnion
}

\author{
Sami Taipale ${ }^{1, *}$, Paula Kankaala ${ }^{2}$, Martin W. Hahn ${ }^{3}$, Roger I. Jones ${ }^{1}$, Marja Tiirola ${ }^{1}$ \\ ${ }^{1}$ Department of Biological and Environmental Science, University of Jyväskylä, PL 35 (YA), 40014 Jyväskylä, Finland \\ ${ }^{2}$ Department of Biology, University of Eastern Finland, Box 111, 80101 Joensuu, Finland \\ ${ }^{3}$ Institute for Limnology, Austrian Academy of Sciences, Mondseestrasse 9, 5310 Mondsee, Austria
}

\begin{abstract}
Heterotrophic processes are considered to prevail in lakes with high terrestrial loading and a high content of dissolved organic carbon. However, previous studies have shown abundant methanotrophic bacteria (MOB) and photoautotrophic green sulphur bacteria (GSB) in some boreal lakes. We used genetic and lipid biomarkers to follow the seasonal succession of the abundance and carbon biomass of the major bacterial groups in Lake Mekkojärvi, a small Finnish polyhumic lake with a large anoxic hypolimnion. Biomarkers were based on length heterogeneity analysis of $16 \mathrm{~S}$ rRNA gene amplification by polymerase chain reaction (PCR) (LH-PCR) and on phospholipid fatty acid (PLFA) analysis. Representative strains closely affiliated to the dominant bacterial groups in the lake were cultured and their characteristic PLFA biomarkers were selected. According to these biomarkers, the relative abundance and biomass of the anaerobic photoautotrophic bacteria (e.g. GSB) were extremely high in the pelagial during summer stratification (on average $47 \%$ of the bacterial rRNA genes and $77 \%$ of the total particulate organic carbon). Type I MOB were especially abundant during autumn mixing, forming on average $32 \%$ - but occasionally up to $73 \%$ - of the carbon biomass. Heterotrophic bacteria affiliated to Actinobacteria and Polynucleobacter spp. together contributed 1 to $8 \%$ of the seasonal carbon biomass in the lake, although their genetic biomarkers were much more common. The results indicate that a significant proportion of the bacterial biomass was formed through methanotrophic and photoautotrophic production, both being comparable with the summer primary production rates of phytoplankton. These findings challenge the current model of the heterotrophic microbial pathway as the principal basis for microbial mobilisation of carbon and energy in freshwater food webs in oxygen-stratified lakes.
\end{abstract}

KEY WORDS: Methanotrophic bacteria · Green sulphur bacteria $\cdot$ Heterotrophic bacteria $\cdot$ Humic lake

\section{INTRODUCTION}

The microbial food web is now recognized as an important component of pelagic food webs in both marine and freshwater ecosystems (Azam et al. 1983, Weisse 2004, Carpenter et al. 2005). In lake ecosystems, bacterial-mediated carbon can originate from primary production within lakes or from terrestrial carbon loading from the catchment. Kritzberg et al. (2006a) showed that the contribution of terrestrial organic carbon to bacterial substrates increased with increasing dissolved organic carbon (DOC) concentrations in lakes, and that terrestrial organic carbon was dominant $(>75 \%$ of total DOC) in high-DOC lakes (DOC $>8.1 \mathrm{~g} \mathrm{C} \mathrm{m}^{-3}$ ). Most of the DOC in boreal dystrophic lakes originates from peatlands and coniferous forested catchments (Kortelainen 1993, Humborg et al. 2004); this DOC influences bacterial community structure in the receiving lakes (Kritzberg et al. 2006b, Lindström et al. 2006).

Most studies on the aquatic microbial foodweb in freshwater lakes have focused on heterotrophic pro- 
cesses and the microbial community in oxic surface waters. Heterotrophic bacteria, especially Actinobacteria and Betaproteobacteria, have been shown to dominate typical freshwater bacterial communities (e.g. Glöckner et al. 2000, Zwart et al. 2002, Hahn 2006, Percent et al. 2008). However, heterotrophic bacterial processes are not necessarily the key processes in energy mobilization in stratified boreal humic lakes that have thick layers of anaerobic water. Methanogenesis by members of the Archaea usually dominates anaerobic carbon mineralization in anoxic freshwaters (Canfield et al. 2005), providing both carbon and energy sources for methane-oxidizing bacteria (MOB, methanotrophs) in the water column (Sundh et al. 2005). Stable isotope analyses have shown that methanotrophic biomass can be an important food source for zooplankton, providing an alternative energy link in many boreal lakes (Bastviken et al. 2003, Taipale et al. 2007, 2008, 2009a). For example, outputs from stable isotope mixing models have suggested that, in small lakes, up to $50 \%$ of zooplankton (Daphnia) biomass may derive from $\mathrm{CH}_{4}$ via $\mathrm{MOB}$ (Taipale et al. 2009a, Kankaala et al. 2010). On the other hand, several studies have indicated consumption and top-down control of MOB by Daphnia (Kankaala et al. 2006, 2007a, Jones \& Lennon 2009), even though analysis of the gut content of Daphnia by molecular methods did not reveal symbiotic or directly grazed MOB (Jones \& Lennon 2009). In addition to methane, hydrogen sulphide $\left(\mathrm{H}_{2} \mathrm{~S}\right)$ and reduced iron $\left(\mathrm{Fe}^{2+}\right)$ are formed under anoxic conditions in stratified lakes and lake sediments, and these reduced elements are oxidized by autotrophic microorganisms, including chemolithoautotrophic bacteria (e.g. Gallionella spp.) and photolithoautotrophic green sulphur bacteria (GSB, e.g. Chlorobium sp.) (Heising et al. 1999, Hadas et al. 2001). Indeed, we previously showed (Taipale et al. 2009b) that the bacterial biomass of a stratified lake, Lake Mekkojärvi, was heavily concentrated in the anoxic layers, where Chlorobium sp. formed the main bacterial group, according to rRNA gene sequencing and fragment analysis.

The suitability of the most commonly used techniques for measuring bacterial production - incorporation of ${ }^{3} \mathrm{H}$-thymidine (Fuhrman \& Azam 1980) or ${ }^{14} \mathrm{C}$ leucine (Kirchman et al. 1985) - may be limited in stratified lakes with diverse bacterial communities because these amino acids are probably not taken up equally by all bacteria (Alonso \& Pernthaler 2006), while phytoplankton may also be able to use these amino acids (Kamjunke \& Tittel 2008). Moreover, such measurements cannot distinguish production by different bacterial groups. On the other hand, although different molecular techniques, such as 5S rRNA length separation (Höfle et al. 1999), fluorescence in situ hybridization (FISH) (Pernthaler et al. 1998) and denaturing-gradient gel electrophoresis (DGGE) (Lindström 2000), have increased our understanding of microbial communities in humic lakes, these techniques alone do not give quantitative information about the bacterial abundance or biomasses. Phospholipid fatty acid (PLFA) analysis is a quantitative method suitable for bacterial biomarker studies (see Boschker \& Middelburg 2002), but the interpretation of the results is usually possible only for broad taxonomic groups. To have specific biomarkers for each functional group, the bacterial community first needs to be characterized, after which target bacteria need to be cultured for PLFA analysis to identify suitable specific biomarkers.

In this study, we applied rRNA and PLFA biomarkers to the relative and quantitative analysis of bacterial biomass in different layers of a small, oxygen-stratified boreal lake, Lake Mekkojärvi, throughout the open-water period (incomplete spring mixing, summer stratification and autumn mixing periods). Specific length heterogeneity PCR (LH-PCR) fragments were selected to monitor the overall succession of certain Gram-positive and Gram-negative heterotrophic bacteria (Actinobacteria and Polynucleobacter spp./Methylophilus sp.), typical MOB and photoautotrophic bacteria (Chlorobium sp.) which had been identified as the major bacterial groups by 16S rRNA gene sequencing during mid-summer stratification (Taipale et al. 2009b). To calculate the carbon biomass, the closest available representatives of these bacterial groups were cultured, PLFA profiles were analyzed, and characteristic PLFA biomarkers were selected for each bacterial group. Microbial activity by ${ }^{14} \mathrm{C}$-leucine uptake, methane oxidation and algal photosynthetic activity were all measured and were compared with the carbon fixation rate of anaerobic photoautotrophic bacteria, described for Lake Mekkojärvi in a previous study (Kuuppo-Leinikki \& Salonen 1992). By combining the 2 independent microbial profiling methods (LH-PCR and PLFA) with the values of the particulate organic carbon (POC) and microbial activity in different layers of water, we were able to make a seasonal evaluation of heterotrophic bacteria, MOB and photoautotrophic bacteria as the major producers and pelagic biomass resources on a wholelake scale.

\section{MATERIALS AND METHODS}

Description of the study lake. Lake Mekkojärvi $\left(61^{\circ} 13^{\prime} \mathrm{N}, 25^{\circ} 8^{\prime} \mathrm{E}\right.$ ) is a small (area: $0.35 \mathrm{ha}$ ) polyhumic

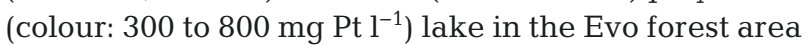
of southern Finland. The lake has a maximum depth of 
$4.3 \mathrm{~m}$ and a mean depth of $2 \mathrm{~m}$, and is strongly stratified in the summer when the oxic epilimnion is very narrow $(0.5$ to $1 \mathrm{~m})$. The lake is naturally acidic $(\mathrm{pH}$ from 5 to 6.5) and it receives a high loading of terrestrial carbon from its catchment. The lake water is dark brown and has a high total concentration of DOC (20 to $45 \mathrm{mg} \mathrm{C}^{-1}$ ). The concentration of dissolved inorganic carbon (DIC) varies between 3 and $12 \mathrm{mg} \mathrm{Cl}^{-1}$. Anoxia during ice-cover causes the lake to be fishless, and the zooplankton community is therefore dominated by large-bodied Daphnia longispina. Further characteristics of Lake Mekkojärvi can be found elsewhere (Arvola et al. 1992, Münster et al. 1999, Taipale et al. 2009b).

Sampling. Samples for PLFA analysis and LH-PCR were collected weekly during spring (16 May to 3 June), summer (11 July to 1 August) and autumn (19 September to 3 October) in 2005. Water samples were taken from the epilimnion (0 to $0.6 \mathrm{~m}$ ), upper metalimnion (0.6 to $1.2 \mathrm{~m})$, lower metalimnion (1.2 to $1.8 \mathrm{~m})$ and anoxic hypolimnion (1.8 to $3.0 \mathrm{~m}$ ) using a Limnos tube sampler (height $60 \mathrm{~cm}$, volume $4.25 \mathrm{l}$ ). Water was filtered through a $100 \mu \mathrm{m}$ mesh net in the field. In the laboratory, 1 to $6 \mathrm{l}$ of lake water from each layer was filtered through Whatman ${ }^{\circledR} \mathrm{GF} / \mathrm{F}$ filters (nominal pore size $0.7 \mu \mathrm{m}$ ) for PLFA analysis. About $50 \mathrm{ml}$ of lake water was filtered through a Filtropur acetylacetate filter unit (0.2 $\mu \mathrm{m}$ pore size; Sarstedt) for the DNA analyses.

Water temperature and oxygen concentration were measured with a YSI 550A probe (Yellow Spring Instruments) at $0.5 \mathrm{~m}$ intervals from the surface to the bottom 2 to 4 times per week; the accuracy of these probes was $\pm 0.3^{\circ} \mathrm{C}$ and $\pm 0.3 \mathrm{mg} \mathrm{O} \mathrm{O}^{-1}$ respectively. Redox potential was measured weekly with a WTW Multiline P3 pH/conductivity meter equipped with a Schott redox-combination electrode. Total nitrogen, total phosphorus, alkalinity, colour, $\mathrm{pH}$ and conductivity were analyzed twice per week using the validated methods of the Finnish Standard Association (www. sfs.fi/en/). POC was measured with a high-temperature combustion method from water samples filtered on a pre-ignited Whatman GF/C glass-fibre filter according to Salonen (1979). For chlorophyll measurements, a pooled water sample $(0.5$ to $1 \mathrm{l})$ from each layer was filtered in the dark on Whatman GF/C filters, extracted in ethanol, and analyzed with a Shimadzu UV-2100 spectrophotometer at wavelengths of 665 and $750 \mathrm{~nm}$ for chlorophyll $a$ and 654 for bacteriochlorophyll $d$ (see Takahashi \& Ichimura 1970). Because the area of spectral peaks of chlorophyll $a$ and bacteriochlorophyll $d$ overlap with each other, the results are presented as total chlorophyll dominated by either chlorophyll a or bacteriochlorophyll $d$, depending on the position of the peak (665 or $654 \mathrm{~nm}$ ) in the spec- trum. The concentration of methane in the water column was measured from samples taken into $60 \mathrm{ml}$ polypropyplene syringes for every $0.6 \mathrm{~m}$ with an AGILENT 6890 N (Agilent Technologies) gas chromatograph equipped with a flame ionization detector (temperature $210^{\circ} \mathrm{C}$, oven $40^{\circ} \mathrm{C}$, PlotQ capillary column,

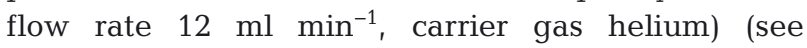
Kankaala et al. 2007a for details).

Production rates by phytoplankton and heterotrophic and methanotrophic bacteria during the spring, summer and autumn seasons $\left(\mathrm{mg} \mathrm{C} \mathrm{m} \mathrm{m}^{-2} \mathrm{~d}^{-1}\right.$ ) were measured in the field (see Taipale et al. 2009b for details). Phytoplankton primary production was measured with the $\mathrm{NaH}^{14} \mathrm{CO}_{3}$ incorporation method $(24 \mathrm{~h}$ incubation) according to Keskitalo \& Salonen (1994). Bacterial biomass production was measured by the incorporation of ${ }^{14} \mathrm{C}$ leucine into bacterial cells (Kirchman et al. 1985, as modified by Tulonen 1993), using $30 \mathrm{nM}$ of ${ }^{14} \mathrm{C}$ leucine (Amersham Biosciences) as the concentration incorporated at in situ water depth and temperature. As the incubation was performed in situ in aerobic incubation tubes containing 0.3 volumes of water and 0.7 volumes of air, we consider that the measurement represented mainly aerobic heterotrophic production and excluded anaerobic photoautotrophic production. Methanotrophic activity in the water column was measured weekly as the $24 \mathrm{~h}$ consumption of $\mathrm{CH}_{4}$ in glass syringes at in situ temperatures for each respective $0.6 \mathrm{~m}$ sampling interval, as described by Kankaala et al. $(2006,2007 \mathrm{~b})$. Net production of MOB was assumed to be $45 \pm 15 \%$ of the methanotrophic activity, based on the reported range of growth efficiency for MOB (King 1992, Templeton et al. 2006). Although we did not measure the production rate of photoautotrophic bacteria (Chlorobi) in this study, we assume that the earlier anaerobic ${ }^{14} \mathrm{C}$-incorporation measurements by Kuuppo-Leinikki \& Salonen (1992) at similar oxygen and temperature conditions in Lake Mekkojärvi are representative for the summer period in our study.

DNA analysis. DNA extraction (using bead-beating and phenol-chloroform extraction), PCR amplification of the 16S rRNA gene (regions V1 to V3), and LHPCR electrophoresis were performed as described previously (Taipale et al. 2009b). We chose to use LHPCR (Suzuki et al. 1998) — as in our previous study of Lake Mekkojärvi (Taipale et al. 2009b) — because it has proved to be a more reproducible and technically less complex method than the more commonly used terminal restriction fragment length polymorphism (T-RFLP), while still giving very good resolution of the whole community structure of complex microbial systems (Mills et al. 2003). LH-PCR analysis is based on the natural length variation of the 16S rRNA gene. In this study, we used the first third of the gene (vary- 


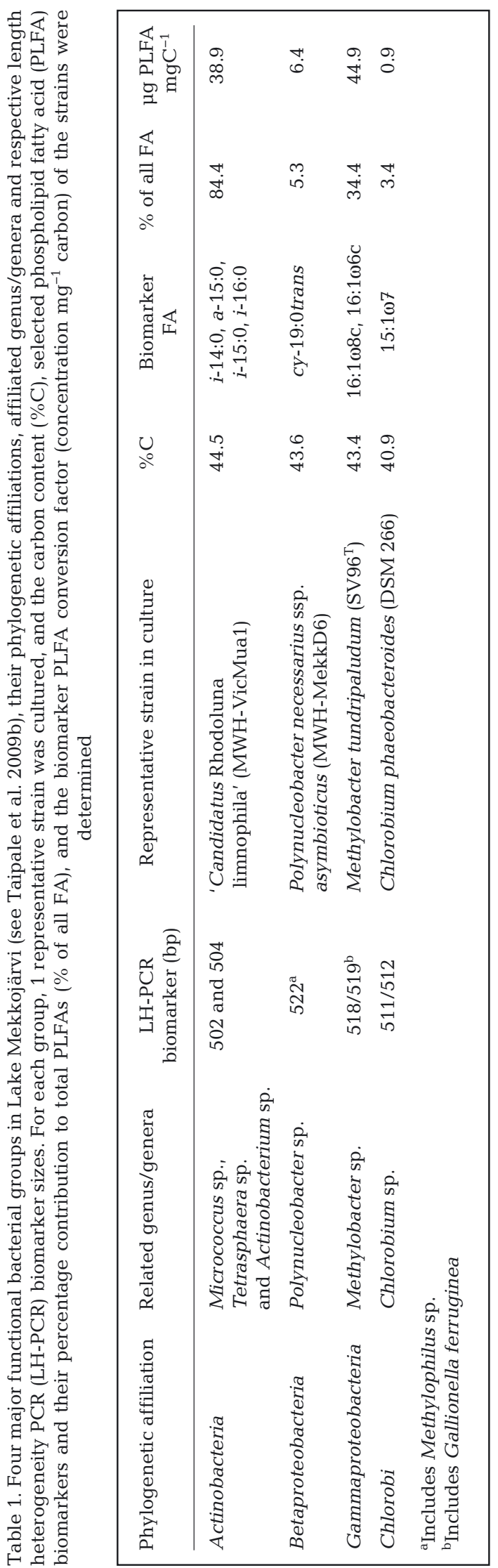

ing between 465 and 565 base pairs) within which some phylogenetic groups have relatively conserved fragment sizes (Tiirola et al. 2003), facilitating taxonomic analysis of the data. The LH-PCR percentage indicates the proportion of the specific biomarker peak area (intensity) of the total peak area of the sample.

PLFA analysis. Phospholipids were extracted, fractionated, saponified and methylated from Whatman GF/F filters and bacterial cell pellets using the modified protocol of Bligh \& Dyer (1959, see Taipale et al. 2009b). For quantification, dipentadecanoylphosphatidylcholine $\left(\mathrm{C}_{38} \mathrm{H}_{76} \mathrm{NO}_{8} \mathrm{P}\right.$, Sigma) was added as an internal standard. Additionally, tridecanoic $\left(\mathrm{C}_{14} \mathrm{H}_{28} \mathrm{O}_{2}\right.$, Sigma $)$, and nonadecanoic $\left(\mathrm{C}_{20} \mathrm{H}_{40} \mathrm{O}_{2}\right.$, Sigma) acid methyl esters were used to quantify methylation efficiency. Strains representative of the main functional bacterial groups of interest-and related as closely as possible to the lake bacteria were selected and cultured. The bacterial strains Candidatus Rhodoluna limnophila MWH-VicMua1 (Hahn 2009) and Polynucleobacter necessarius ssp. asymbioticus MWH-Mekk-D6 (Hahn et al. 2009) the latter actually isolated from Lake Mekkojärvirepresented Actinobacteria (Gram-positive) and Betaproteobacteria (Gram-negative) heterotrophic bacteria, respectively. These strains were grown in liquid NSY medium (Hahn et al. 2004) on a rotary shaker at room temperature. Methylobacter tundripaludum SV96 $^{\mathrm{T}}$ (Wartiainen et al. 2006) was cultured on M2 medium (Deutsche Sammlung von Mikroorganismen und Zellkulturen, DSMZ; medium 921, $\mathrm{pH} 6.8,+23^{\circ} \mathrm{C}, 120 \mathrm{rpm}$ ) with $\mathrm{KNO}_{3}$ as a nitrogen source. Chlorobium phaeobacteroides DSM 267 (Pfennig 1968, emend. Imhoff 2003) was obtained from the DSMZ. After culture, the samples were freeze-dried and their carbon contents were analyzed using a Carlo-Erba Flash 1112 series Element Analyzer connected to a Thermo Finnigan Delta Plus Advantage IRMS. The PLFA profiles of freeze-dried pure cultures were extracted as described by Taipale et al. (2009a).

Biomarkers. The selection of LH-PCR biomarkers (Table 1) was based on the sizes of over 400 16S rRNA gene sequences obtained from a previous study of Lake Mekkojärvi (Taipale et al. 2009b). The bulk (91\%) of the sequences with an LH-PCR size of 502 to $504 \mathrm{bp}$ were affiliated to Actinobacteria-and especially to Candidatus Nostocoida limicola (38\%) and these sizes covered $83 \%$ of all actinobacterial sequences. The sequence size 511 or 512 bp was totally $(100 \%)$ affiliated to the phylum Chlorobi and therein to the genus Chlorobium. The sequence size 518 bp was totally $(100 \%)$ affiliated to Methylobacter spp., while the size 519 bp was affiliated to Gallio- 
nella ferruginea. However, as we were not able to separate lengths $518 \mathrm{bp}$ and $519 \mathrm{bp}$ accurately in our LH-PCR gel runs these sizes were combined. Nevertheless, Gallionella ferruginea was more common in the anoxic water column than in the oxic epilimnion, so the combined size (518/519) was affiliated mainly to Methylobacter spp. in the oxic epilimnion. The sequence size of $522 \mathrm{bp}$ was affiliated to the genera Polynucleobacter ( $75 \%$ of sequences) and Methylophilus (19\% of sequences), covering $33 \%$ of all betaproteobacterial sequences.

PLFA biomarkers were selected for maximum specificity based on the comparison between PLFA profiles of cultured bacteria (Table 1 ; for full PLFA profiles see Appendix 1) and reported PLFA profiles of other bacteria (Ratledge \& Wilkinson 1988). The PLFA analysis of Candidatus Rhodoluna limnophila revealed that $84.4 \%$ of all its PLFAs belonged to iso- and anteisobranched PLFAs. Polynucleobacter necessarius ssp. asymbioticus had a very specific PLFA, trans-2-octylcyclopropaneoctanoic acid (9,10-cy-19:0trans, hereafter cy-19:0), which was chosen as the specific biomarker FA for Polynucleobacter spp. PLFAs 16:118c and 16:1 $166 \mathrm{c}$ were selected as biomarkers for the genus Methylobacter and for the MOB belonging to Gammaproteobacteria (type I). The alphaproteobacterial MOB

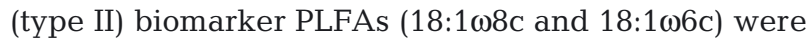
not found in water samples from the lake, and thus MOB type II was excluded from the study. The PLFA profile of Chlorobium phaeobacteroides DSM 267 revealed that this microbe has PLFA 15:107, which is quite rare in other bacteria; hence, it was selected as a PLFA biomarker for this genus.

The contribution of each bacterial group in the PLFA profile (PLFA\%) was calculated by dividing the proportion of the biomarker PLFA (of all sample PLFAs) by the species-specific proportion of biomarker PLFAs in the representative pure culture (Table 1). To calculate the biomass concentration $(\mu \mathrm{g}$ $\mathrm{C}^{-1}$ ) for each bacterial group, the biomarker PLFA concentration was divided by the PLFA conversion factor (amount of the biomarker PLFA $\mathrm{mg}^{-1}$ carbon in the representative bacterial pure culture, $\mu \mathrm{g}$ PLFA $\mathrm{mgC}^{-1}$, Table 1). The relative biomass of each bacterial group (biomass\%) was calculated by dividing biomass concentration of the bacterial group by the concentration of POC:

$$
\text { Biomass } \%=(x / y) /[\mathrm{POC}] \times 100 \%
$$

where $x=$ concentration of selected biomarker PLFAs in the sampled water layer ( $\mu$ g PLFA ${ }^{-1}$ ), and $y=$ PLFA conversion factor for the representative pure culture $\left(\mu \mathrm{g}\right.$ PLFA $\left.\mathrm{mgC}^{-1}\right)$.

The average biomass $\%$ for the whole water column was weighted by POC and volume by integrating the
PLFA biomasses of the water column and dividing it by the integrated POC content.

Statistical analyses. All statistical analyses of the data were done with SPSS (17.02) program package. The biomasses of GSB and MOB were integrated for the whole water column and compared with those of heterotrophic bacteria using paired $t$-tests. To describe changes in the microbial community during the ice-free (open-water) period, and to find out correlations between the measured variables-relative abundance and biomass of selected bacterial groups by LH-PCR and PLFA analyses, proportion of the biomass of the total POC, phytoplankton primary production, heterotrophic bacterial production, methanotrophic activity, concentrations of oxygen and methane, as well as the values of redox potential and temperature - at 4 depths in the whole water column, the data were analyzed with the principal component analysis (PCA) with Varimax rotation. All data are given as mean $\pm \mathrm{SD}$.

\section{RESULTS}

\section{Physical and chemical conditions}

In 2005, ice-melt occurred in early May, after which the lake was strongly stratified in terms of temperature and oxygen until mid-October when autumn mixing occurred (Fig. 1). Traces of oxygen $\left(<0.3 \mathrm{mg} \mathrm{O}_{2} \mathrm{l}^{-1}\right)$ were detectable at $1.0 \mathrm{~m}$, but the water column was totally anoxic at $1.5 \mathrm{~m}$ and below. Redox potential dropped sharply between $1.2 \mathrm{~m}$ and $1.8 \mathrm{~m}$, showing that the oxic-anoxic boundary layer was between these depths during the stratified period. Although negative redox potentials were measured at $1.8 \mathrm{~m}$ in autumn, very low (less than $-30 \mathrm{mV}$ ) redox potentials were measured only near the bottom sediment $(2.4 \mathrm{~m})$. Following mixing in the whole water column on 18 October, the redox potential increased to $230 \mathrm{mV}$ above $2.4 \mathrm{~m}$. The concentration of $\mathrm{CH}_{4}$ in the water column followed a pattern opposite to that of oxygen and redox potential.

The main chemical properties of the lake during spring, summer and autumn are summarized in Table 2. With the exception of DOC and $\mathrm{NO}_{3}+\mathrm{NO}_{2}-\mathrm{N}$ in the autumn, the concentrations of the other measured chemical compounds, as well as $\mathrm{pH}$ and water colour values, were higher in the hypolimnion than in the epilimnion. High concentrations of chlorophyll, dominated by bacteriochlorophyll $d$, were measured in the hypolimnion, especially during the spring and summer $\left(>200 \mu \mathrm{g} \mathrm{l}^{-1}\right)$; these concentrations always exceeded that of chlorophyll $a$, which dominated pigments in the epilimnion. 
A) Oxygen
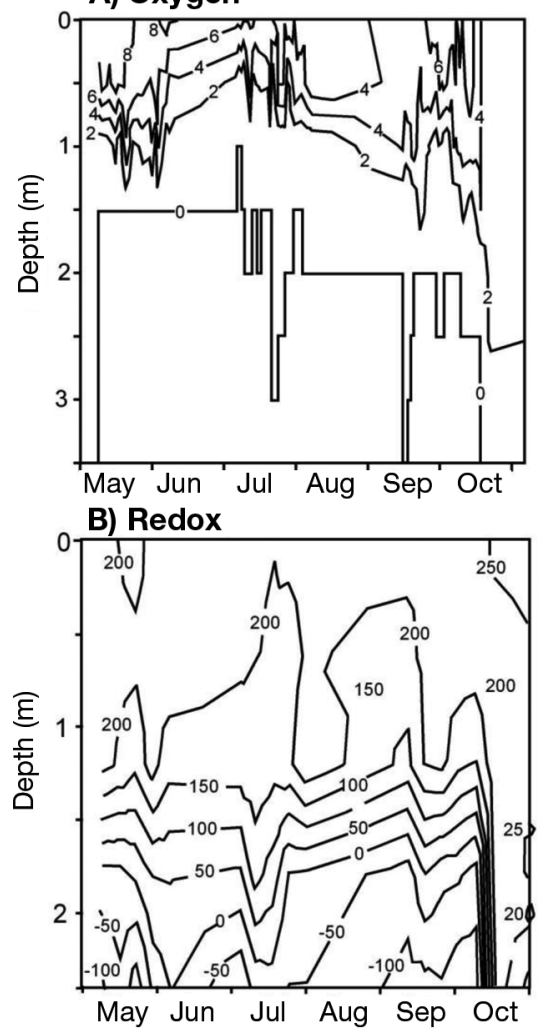

C) Temperature
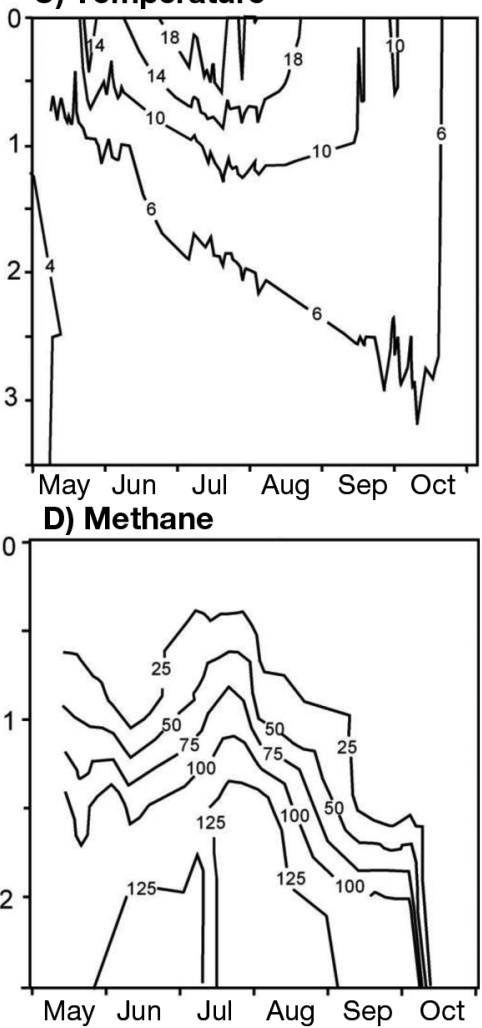

Fig. 1. (A) Oxygen $\left(\mathrm{mg} \mathrm{l}^{-1}\right)$, (B) redox $(\mathrm{mV})$, (C) temperature $\left({ }^{\circ} \mathrm{C}\right)$, and (D) methane concentration $\left(\mu \mathrm{mol} \mathrm{l^{-1 }}\right)$ profiles in Lake Mekkojärvi through the 2005 open-water season

further during the autumn (Fig. 2). Production by heterotrophic bacteria, as measured by uptake of ${ }^{14} \mathrm{C}$-leucine, did not vary greatly between the seasons, but was slightly higher in autumn $\left(12 \pm 6 \mathrm{mg} \mathrm{C} \mathrm{m}^{-2}\right.$ $\left.\mathrm{d}^{1}\right)$ than in spring and summer $(7 \pm 1 \mathrm{mg} \mathrm{C}$ $\mathrm{m}^{-2} \mathrm{~d}^{-1}$ and $8 \pm 3 \mathrm{mg} \mathrm{C} \mathrm{m} \mathrm{m}^{-2}$, respectively). The highest levels of methane oxidation were measured in the whole water column during the autumn mixing period $\left(190 \pm 170 \mathrm{mg} \mathrm{C} \mathrm{m}^{-2} \mathrm{~d}^{-1}\right)$, but during the spring and summer seasons high activities were also measured in the metalimnetic layers. Even assuming that only $45 \pm 15 \%$ of the consumed methane was incorporated by MOB cells, in autumn this net production of MOB was several fold higher (85 \pm $28 \mathrm{mg} \mathrm{C} \mathrm{m}^{-2} \mathrm{~d}^{-1}$ ) than production by heterotrophic bacteria or primary production (Fig. 2). The net production of MOB also exceeded primary production during the summer period and exceeded heterotrophic bacterial production during both spring and summer. During the summer period the activity of photoautotrophic bacteria $\left(40 \pm 10 \mathrm{mg} \mathrm{C} \mathrm{m}^{-2} \mathrm{~d}^{-1}\right)$ was estimated to be at the same level as net production by MOB.

\section{Primary production and microbial activity}

The highest primary production by algae was measured during spring $\left(58 \pm 42 \mathrm{mg} \mathrm{C} \mathrm{m}^{-2} \mathrm{~d}^{-1}\right)$. During summer, the mean primary production $(26 \pm 13 \mathrm{mg} \mathrm{C}$ $\mathrm{m}^{-2} \mathrm{~d}^{-1}$ ) was about half of that in spring and it declined

\section{Fluctuation in the major bacterial groups revealed by LH-PCR}

Altogether, 30 distinct LH-PCR fragments were found from the whole water column. However, the focused biomarker sizes (502, 504, 511/512, 518/519

Table 2. Mean \pm SD chemical properties of the epilimnion (0 to $0.6 \mathrm{~m}$ ) and hypolimnion (1.8 to $3.0 \mathrm{~m}$ ) of Lake Mekkojärvi during spring, summer and autumn in 2005. Dominance of chlorophyll $a$ or bacteriochlorophyll $d$ is shown within brackets in the respective layers

\begin{tabular}{|c|c|c|c|c|c|c|}
\hline & \multicolumn{2}{|c|}{$\longrightarrow$ Spring } & \multicolumn{2}{|c|}{ Summer } & \multicolumn{2}{|c|}{ Autumn } \\
\hline & $0-0.6 \mathrm{~m}$ & $1.8-3.0 \mathrm{~m}$ & $0-0.6 \mathrm{~m}$ & $1.8-3.0 \mathrm{~m}$ & $0-0.6 \mathrm{~m}$ & $1.8-3.0 \mathrm{~m}$ \\
\hline $\mathrm{DOC}\left(\mathrm{mg} \mathrm{C} \mathrm{l}^{-1}\right)$ & $26.8 \pm 1.1$ & $26.2 \pm 0.7$ & $22.3 \pm 1.7$ & $21.9 \pm 0.9$ & $24.9 \pm 1.6$ & $20.9 \pm 0.9$ \\
\hline $\mathrm{POC}\left(\mathrm{mg} \mathrm{C} \mathrm{l}^{-1}\right)$ & $0.4 \pm 0.1$ & $1.5 \pm 0.3$ & $0.3 \pm 0.1$ & $1.5 \pm 0.5$ & $0.3 \pm 0.1$ & $0.6 \pm 0.1$ \\
\hline $\mathrm{DIC}\left(\mathrm{mg} \mathrm{C} \mathrm{l}^{-1}\right)$ & $3.1 \pm 0.9$ & $12.2 \pm 2.5$ & $3.5 \pm 0.8$ & $14.0 \pm 1.6$ & $5.0 \pm 1.6$ & $11.1 \pm 2.9$ \\
\hline $\mathrm{CH}_{4}\left(\mu \mathrm{mol} \mathrm{l} \mathrm{l}^{-1}\right)$ & $1.5 \pm 1.1$ & $121.2 \pm 5.8$ & $11.6 \pm 7.3$ & $133.0 \pm 9.0$ & $5.9 \pm 7.6$ & $101.6 \pm 60.6$ \\
\hline $\mathrm{Chl} \mathrm{a/d}\left(\mu \mathrm{g} \mathrm{Chl} \mathrm{l^{-1 } )}\right.$ & $7.2 \pm 4.0(a)$ & $136.3 \pm 10,5(d)$ & $11.2 \pm 3.1(a)$ & $220.0 \pm 15.2(d)$ & $11.2 \pm 3.1(a)$ & $92.4 \pm 45.9(d)$ \\
\hline $\mathrm{pH}$ & $5.5 \pm 0.1$ & $6.0 \pm 0.1$ & $5.8 \pm 0.2$ & $6.1 \pm 0.1$ & $6.0 \pm 0.3$ & $6.2 \pm 0.1$ \\
\hline Water colour (mg Pt l-1) & $412.0 \pm 38.0$ & $464.0 \pm 31.0$ & $411.0 \pm 50.0$ & $442.0 \pm 24.0$ & $488.0 \pm 3.0$ & $461.0 \pm 12.0$ \\
\hline $\mathrm{N}$ as $\mathrm{NO}_{2}+\mathrm{NO}_{3}\left(\mu \mathrm{g} \mathrm{N} \mathrm{l}^{-1}\right)$ & $27.0 \pm 9.9$ & $18.5 \pm 13.4$ & $22.0 \pm 12.7$ & $13.5 \pm 9.2$ & $13.5 \pm 0.7$ & $8.5 \pm 0.7$ \\
\hline $\mathrm{N}$ as $\mathrm{NH}_{4}\left(\mu \mathrm{g} \mathrm{N} \mathrm{l}^{-1}\right)$ & $12.0 \pm 1.4$ & $186.5 \pm 40.3$ & $22.3 \pm 8.2$ & $258.8 \pm 42.2$ & $25.0 \pm 4.2$ & $296.5 \pm 4.9$ \\
\hline total $\mathrm{N}\left(\mu \mathrm{g} \mathrm{N} \mathrm{l^{-1 }}\right)$ & $611.0 \pm 7.1$ & $880.0 \pm 31.1$ & $574.0 \pm 70.7$ & $914.5 \pm 34.6$ & $607.0 \pm 32.5$ & $911.0 \pm 20.0$ \\
\hline $\mathrm{P}$ as $\mathrm{PO}_{4}\left(\mu \mathrm{g} \mathrm{P}{ }^{-1}\right)$ & $1.5 \pm 0.7$ & $4.0 \pm 2.8$ & $1.5 \pm 0.7$ & $5.5 \pm 2.1$ & $2.5 \pm 0.7$ & $9.5 \pm 0.7$ \\
\hline total $\mathrm{P}\left(\mu \mathrm{g} \mathrm{P} \mathrm{l}^{-1}\right)$ & $14.5 \pm 3.5$ & $29.0 \pm 1.4$ & $10.0 \pm 2.8$ & $34.0 \pm 1.4$ & $10.0 \pm 2.8$ & $32.0 \pm 1.2$ \\
\hline
\end{tabular}




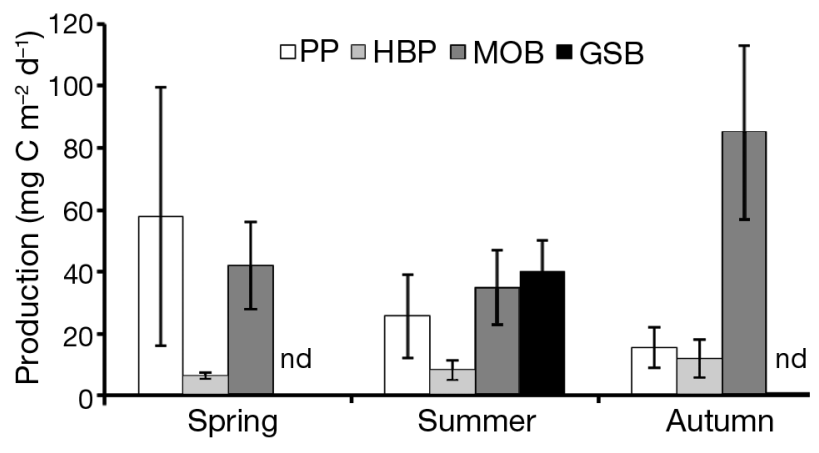

Fig. 2. Mean \pm SD primary production $(\mathrm{PP})$, heterotrophic bacterial production (HBP), net production of methaneoxidizing bacteria (MOB) and the production of photoautotrophic bacteria (GSB) for spring, summer and autumn periods. $\mathrm{nd}=$ no data

and $522 \mathrm{bp}$ ) contributed 49 to $92 \%$ of the total LH-PCR intensity throughout the study period (Fig. 3A-D). The lowest relative contribution of these selected sizes was detected on 5 July, when fragments of size $470 \mathrm{bp}$ and $535 \mathrm{bp}$ were especially abundant (together 13 to $22 \%$ of the total LH-PCR intensity) in the epilimnion and upper metalimnion.

The proportion of Actinobacteria-affiliated LH-PCR sizes (502 and $504 \mathrm{bp}$ ) varied greatly from one week to another in the oxic epilimnon. The lowest contribution there (3\%) was measured during spring and the greatest dominance $(43 \%)$ during summer. However, the proportion of actinobacterial LH-PCR biomarkers was minor $(<2 \%)$ in both the lower metalimnon and the hypolimnion during stratification.

The LH-PCR biomarker for Polynucleobacter spp. and Methylophilus sp. (522 bp) was dominant in the epilimnion and upper metalimnion throughout the study, but was especially abundant at the beginning of the spring, and again during autumn mixing, when a large contribution of Methylophilus-assigned bacteria in the water column was likely. The peak 518/519 bp, which could not be further resolved and therefore was assigned to both Methylobacter sp. and Gallionella sp., was abundant in the whole water column.

LH-PCR showed a high stability of the major biomarkers in the anaerobic water column when compared to the aerobic water layers. Based on the specific LH-PCR biomarker (511 bp) for Chlorobium sp. this genus dominated the bacterioplankton community in the anaerobic water layers during spring and summer (45 to $74 \%$ of the LH-PCR peak intensity) with the greatest relative contribution during the spring period. During autumn mixing and aeration, the population collapsed dramatically-first in the metalimnion, after the partial overturn in September, and then in the hypolimnion after the full overturn in October.

\section{Fluctuation in the major bacterial groups revealed by PLFA biomarkers}

A total of 64 PLFAs were detected in the lake water column during the study period, but fewer than 10 of these accounted for more than $90 \%$ of all PLFAs. The water column PLFA profile in the oxic epilimnion changed rapidly between weekly samplings, as well as between the epilimnion and upper metalimnion, but was relatively stable in the anoxic water column throughout the open-water season (Fig. 3).

On average, PLFAs of Actinobacteria contributed $4 \%$ of all PLFAs in the epilimnion and metalimnion (Fig. 3E-H). The proportional contribution of Actinobacteria increased in the epilimnion and upper metalimnion through the open-water season and was highest $(9 \pm 1 \%)$ during the autumn mixing. The calculated biomass of Actinobacteria also increased from spring towards autumn, and in the epilimnion and upper metalimnion it averaged $6 \pm 5 \mu \mathrm{g} \mathrm{Cl}^{-1}, 30 \pm 21 \mu \mathrm{g} \mathrm{Cl}^{-1}$ and $45 \pm 27 \mu \mathrm{g} \mathrm{C}^{-1}$ for spring, summer and autumn, respectively (Fig. 4). The highest individual values were measured during the autumn for Actinobacteria.

The contribution of Polynucleobacter spp. varied from 0 to $30 \%$ of PLFAs in the epilimnion and upper metalimnion with no clear pattern. The highest value was measured from the upper metalimnion directly after ice melt (on 8 May). The estimated PLFA biomass of Polynucleobacter spp. varied from 0 to $94 \mu \mathrm{g} \mathrm{C} \mathrm{l}^{-1}$ in the epilimnion and upper metalimnion, and was below the detection limit during spring. The average biomass of Polynucleobacter spp. was $9 \pm 30 \mu \mathrm{g} \mathrm{Cl}^{-1}, 19 \pm 14 \mu \mathrm{g}$ $\mathrm{C}^{-1}$ and $20 \pm 21 \mu \mathrm{g} \mathrm{Cl^{-1 }}$ in the epilimnion and upper metalimnion for spring, summer and autumn seasons, respectively.

The PLFAs specific for type I MOB were prominent at all depths, but the contribution varied greatly between the weekly samplings. The highest proportional PLFA contributions (51 $\pm 5 \%$, PLFA $\%$ ) were measured in the oxic epilimnion during autumn mixing events, but high $(40 \pm 5 \%)$ proportions were also measured occasionally during the summer (Fig. 3E-H). However, the highest biomass of MOB type I $\left(760 \pm 55 \mu \mathrm{g} \mathrm{C} \mathrm{l}^{-1}\right)$ was measured from the lower metalimnion and hypolimnion during mid-summer on 25 July (Fig. 4). During autumn, a relatively high concentration of MOB type I was measured from the whole water column on 2 different occasions: first, when the water column was mixed partially (26 September), and later during the complete water column turnover (18 October). Seasonal succession of the microbial community was most clearly seen in the oxic epilimnion, where the biomass of MOB type I increased from $8 \pm 2 \mu \mathrm{g} \mathrm{C}^{-1}$ to $36 \pm$ $24 \mu \mathrm{g} \mathrm{Cl}^{-1}$, and $160 \pm 200 \mu \mathrm{g} \mathrm{C}^{-1}$ for spring, summer and autumn, respectively. 

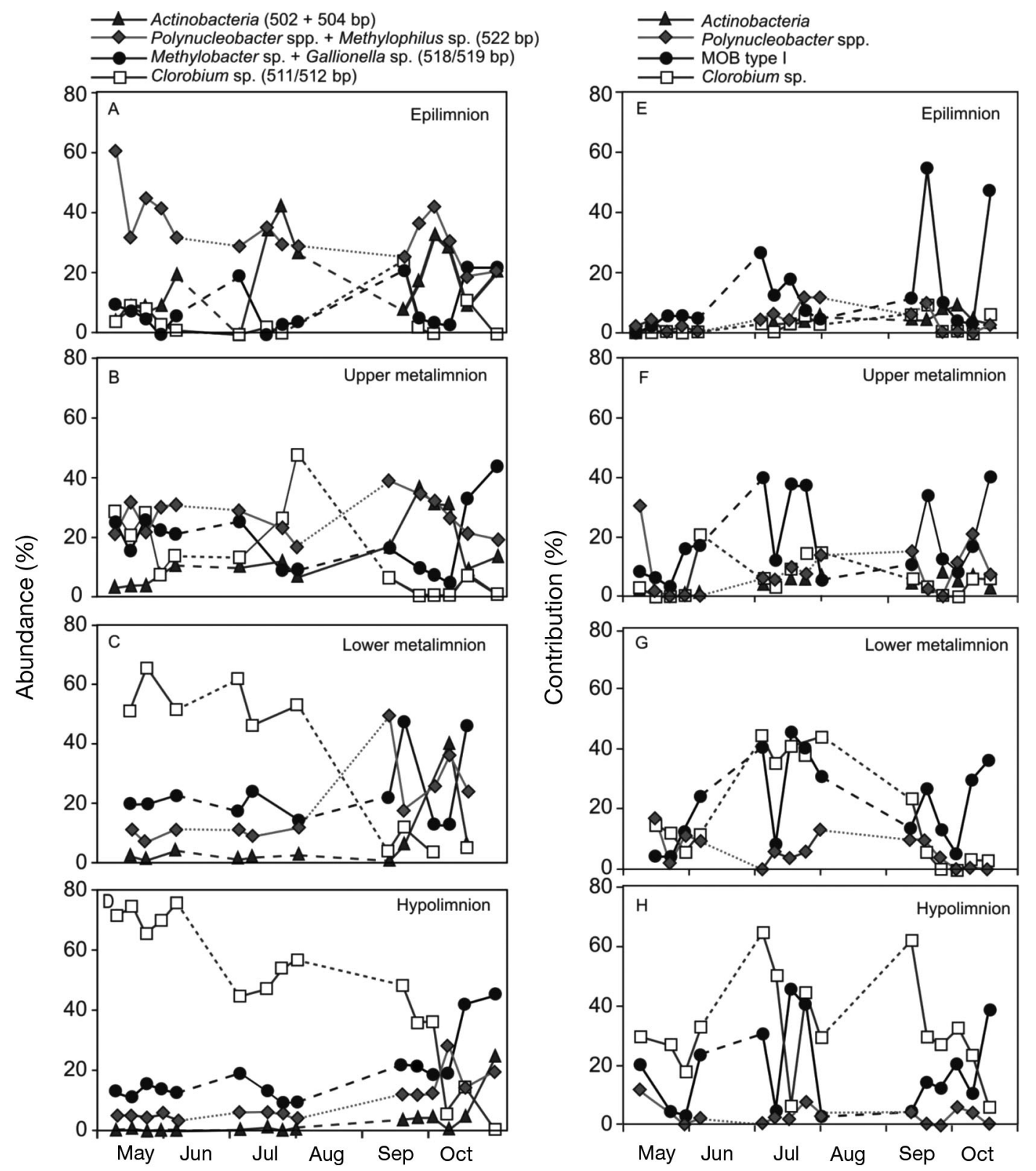

Fig. 3. Relative abundance (\%) of 16S rRNA gene sequences assigned to Actinobacteria, Polynucleobacter spp./Methylophilus sp., Methylobacter sp./Gallionella sp. and Chlorobium sp. based on related length heterogeneity PCR (LH-PCR) biomarkers (size in brackets) in (A) epilimnion (0 to $0.6 \mathrm{~m})$, (B) upper metalimnion (0.6 to $1.2 \mathrm{~m})$, (C) lower metalimnon (1.2 to $1.8 \mathrm{~m})$, and (D) hypolimnion (1.8 to $3.0 \mathrm{~m}$ ). (E-H) The relative contribution (PLFA\%) to the total phospholipid fatty acids (PLFAs) of Actinobacteria, Polynucleobacter spp., methane-oxidizing bacteria (MOB) type I and Chlorobium sp. See Table 2 for the corresponding depths and sampling times

The highest PLFA\% $(53 \pm 11 \%)$ of Chlorobium sp. was measured during summer stratification from the lower metalimnion and hypolimnion (Fig. 3E-H), after which the relative contributions decreased drastically due to autumn mixing. A minor contribution of PLFAs of Chlorobium sp. $(4 \pm 5 \%)$ was also detected in the oxic epilimnion and upper metalimnion. Seasonal succession was very clear: after ice melt in spring, the bio- mass of Chlorobium sp. (Fig. 4) increased in the hypolimnion to a high level by the beginning of June (mean value $740 \pm 475 \mu \mathrm{g} \mathrm{C}^{-1}$ ), and later even higher $\left(1465 \pm 630 \mu \mathrm{g} \mathrm{C} \mathrm{l}^{-1}\right)$ in the lower metalimnion and hypolimnion. During autumn, the biomass of Chlorobium sp. collapsed first in the lower metalimnion and, after complete water column turn-over, also in the hypolimnion. 
Average abundance and biomass of methanotrophic and photoautotrophic bacteria

When the LH-PCR data for the entire water column were integrated over the whole study period, LH-PCR biomarkers assigned to the major heterotrophic bacte-
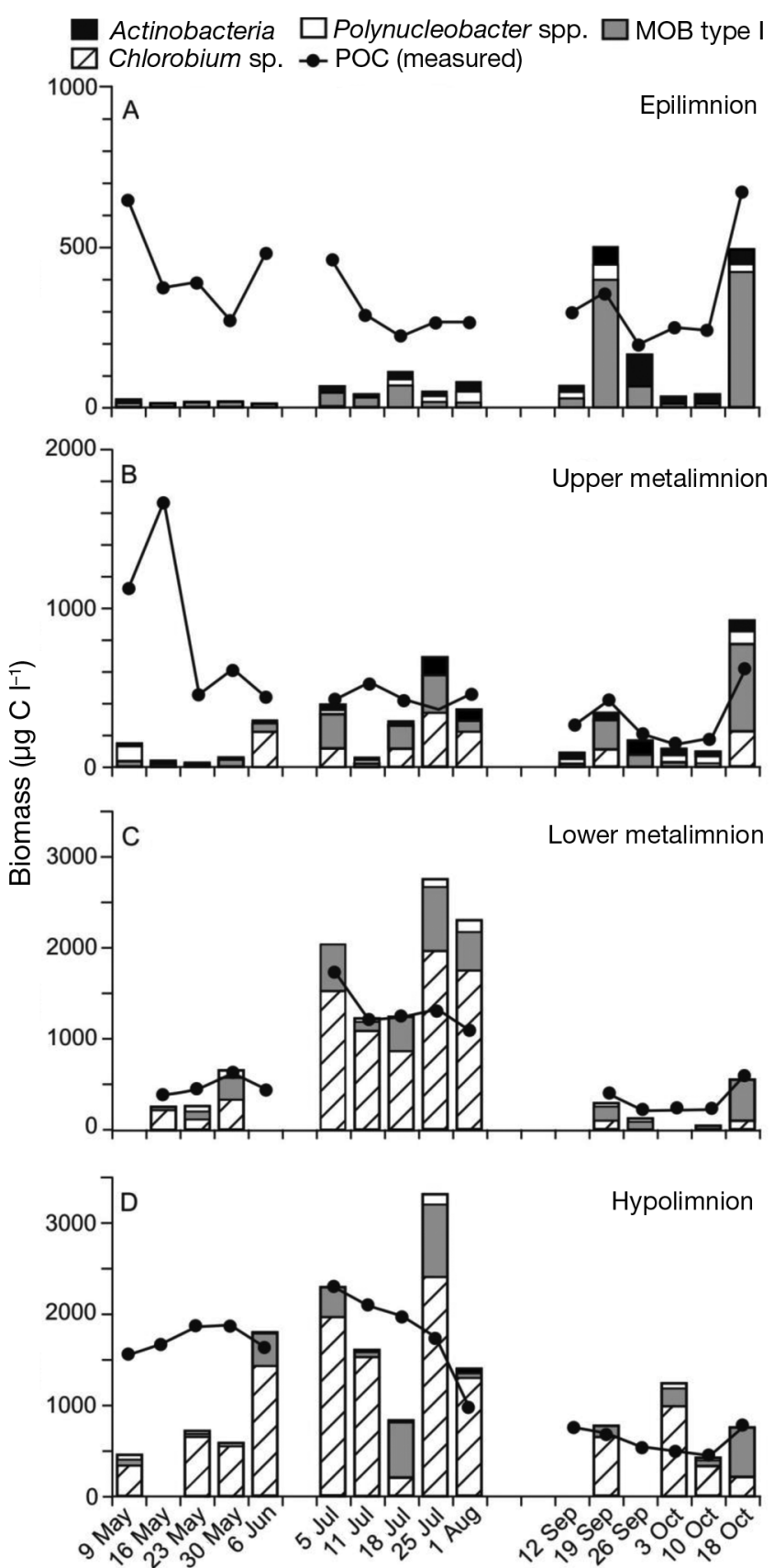

Fig. 4. Biomass ( $\mathrm{g} \mathrm{C}^{-1}$ ) of Actinobacteria, Polynucleobacter spp., methane-oxidizing bacteria (MOB) type I and Chlorobium sp. as calculated from the biomarker phospholipid fatty acids in (A) epilimnion ( 0 to $0.6 \mathrm{~m}$ ), (B) upper metalimnion (0.6 to $1.2 \mathrm{~m}),(\mathrm{C})$ lower metalimnon (1.2 to $1.8 \mathrm{~m})$, and (D) hypolimnion $(1.8$ to $3.0 \mathrm{~m})$. Also shown is the particulate organic carbon (POC) from each layer ria (Actinobacteria and Polynucleobacter spp./Methylophilus sp.) contributed on average $10 \pm 7 \%$ and $19 \pm$ $5 \%$ of the total peak intensity, respectively, whereas peaks assigned to Methylobacter spp./Gallionella sp. contributed $18 \pm 9 \%$, and peaks specific to Chlorobium spp. contributed $29 \pm 17 \%$ of the intensity. In these values, sample depth volumes were taken into account, but the actual biomass of bacteria in each layer was not. Based on the biomass estimates (PLFA and POC), the bacterial biomass of the lake was not evenly distributed, and therefore the direct mean of the LHPCR proportions may underestimate bacteria in the anaerobic water layers. Therefore, the seasonal significance of the microbial groups was recalculated based on the mean relative abundance and relative biomass (Table 3) weighted by the POC concentration in each water layer. After weighting, the relative abundance of Chlorobium sp., based on the DNA analysis, increased from $29 \pm 17 \%$ to $38 \pm 20 \%$, as the biomass was more concentrated in the anaerobic zones, where photoautotrophic bacteria prevailed. In contrast, the weighing had little effect on MOB $(18 \pm 9 \%$ without weighting and $19 \pm 10 \%$ after weighting), while values for

Table 3. Relative significance of the major bacterial groups in the Lake Mekkojärvi water column based on their relative abundance - length heterogeneity PCR (LH-PCR) resultand relative carbon biomass - proportion of the POC, based on phospholipid fatty acid analysis - both weighted by the volume and particulate organic carbon concentration of the sampling depth. MOB = methane-oxidizing bacteria. Values are means $( \pm \mathrm{SD})$ based on all seasonal sampling occasions

\begin{tabular}{|c|c|c|}
\hline Season & $\begin{array}{c}\text { Relative } \\
\text { abundance (\%) }\end{array}$ & $\begin{array}{c}\text { Relative } \\
\text { biomass (\%) }\end{array}$ \\
\hline \multicolumn{3}{|c|}{ Actinobacteria } \\
\hline Spring & $2 \pm 1$ & $0 \pm 0$ \\
\hline Summer & $3 \pm 1$ & $1 \pm 2$ \\
\hline Autumn & $13 \pm 7$ & $4 \pm 2$ \\
\hline Average & $7 \pm 7$ & $2 \pm 2$ \\
\hline \multicolumn{3}{|c|}{ Polynucleobacter spp. ${ }^{\text {a }}$} \\
\hline Spring & $12 \pm 3$ & $1 \pm 1$ \\
\hline Summer & $9 \pm 0$ & $2 \pm 2$ \\
\hline Autumn & $21 \pm 4$ & $4 \pm 2$ \\
\hline Average & $15 \pm 6$ & $3 \pm 2$ \\
\hline \multicolumn{3}{|c|}{ MOB type $I^{b}$} \\
\hline Spring & $14 \pm 1$ & $6 \pm 6$ \\
\hline Summer & $13 \pm 4$ & $26 \pm 19$ \\
\hline Autumn & $26 \pm 13$ & $32 \pm 23$ \\
\hline Average & $19 \pm 10$ & $22 \pm 20$ \\
\hline \multicolumn{3}{|c|}{ Chlorobium sp. } \\
\hline Spring & $56 \pm 3$ & $28 \pm 24$ \\
\hline Summer & $47 \pm 4$ & $77 \pm 47$ \\
\hline Autumn & $16 \pm 13$ & $63 \pm 52$ \\
\hline Average & $38 \pm 20$ & $55 \pm 45$ \\
\hline
\end{tabular}



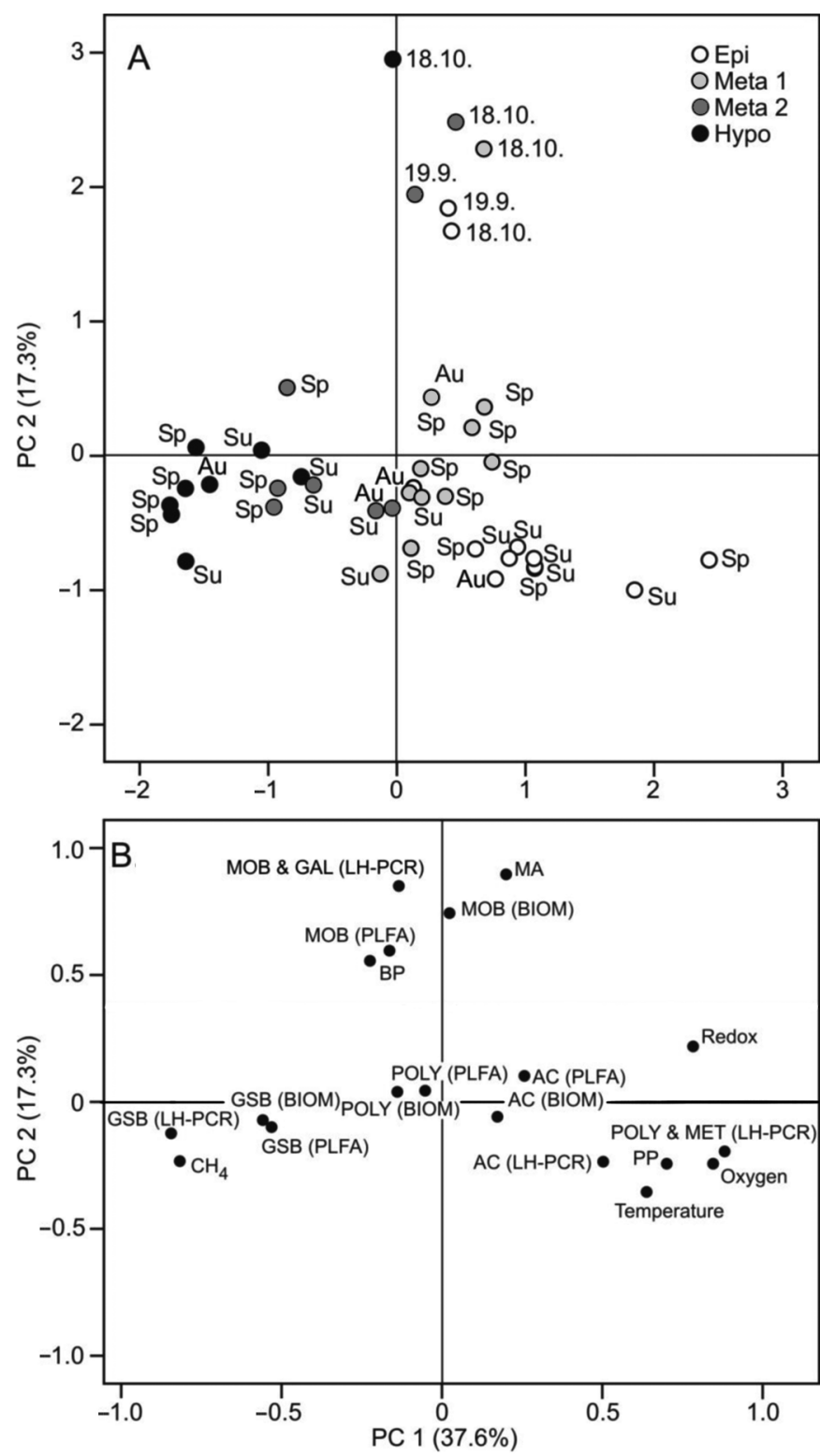

Fig. 5. (A) Principal component analysis (PCA) of spring (Sp), summer $(\mathrm{Su})$ and autumn $(\mathrm{Au})$ water samples from different lake depths $($ Epi $=$ epilimnion, Meta $1=$ upper metalimnion, Meta 2 = lower metalimnion and Hypo = hypolimnion). The results of the dates of partial mixing (19 September $=19.9$.) and complete mixing (18 October $=18.10$. $)$ of the water column are shown separately. (B) The first component ( $x$ axis) was positively correlated with the redox potential, oxygen, temperature and primary production (PP), as well as the length heterogeneity PCR (LH-PCR) biomarkers related to Actinobacteria (AC) and Polynucleobacteria spp./Methylophilus sp. (POLY \& MET), and negatively correlated with the concentration of methane $\left(\mathrm{CH}_{4}\right)$ and the relative proportion of the LH-PCR and phospholipid fatty acid (PLFA) biomarkers and the proportional biomass (BIOM) related to Chlorobium sp. (GSB). The second component ( $y$ axis) was positively correlated with methanotrophic activity (MA), heterotrophic bacterial production (BP), as well as the LH-PCR and PLFA biomarkers and proportional biomass of methane-oxidizing bacteria (MOB)
Actinobacteria and Polynucleobacter spp./Methylophilus sp. decreased significantly.

Seasonal means of biomass values revealed that, during summer, Chlorobium sp. dominated and contributed $77 \pm 47 \%$ of the measured POC, whereas type I MOB contributed $26 \pm 19 \%$. During autumn, type I MOB dominated and contributed $32 \pm 23 \%$, although overturn caused some peaking of MOB values (73\%). In the autumn, the collapse of the Chlorobium sp. population was reflected by large fluctuations in the biomass ( $63 \pm 52 \%$ of the measured POC). The contributions of Actinobacteria and Polynucleobacter spp. were minor.

In the whole dataset, the daily PLFA biomass of the major heterotrophic bacteria (Actinobacteria, Polynucleobacter spp.) was significantly lower than that of either photoautotrophic bacteria $(t=3.625, \mathrm{p}=0.002$, $\mathrm{df}=15)$ or MOB $(t=3.063, \mathrm{p}=0.008, \mathrm{df}=15)$.

\section{Microbial community related to environmental variables}

PCA showed high communalities among all variables (0.448 to 0.945). The first principal component (PC) explained $37.6 \%$ of the overall variability (Fig. 5A) and it located the microbial community of the epilimnion to the right side of the $x$-axis, and the microbial community of the anoxic hypolimnion to the left side; thus, this component could be considered a vertical microbial community component. It was positively correlated (Fig. 5B) with redox potential, oxygen, temperature and primary production as well as the relative LH-PCR abundance of Actinobacteria and Betaproteobacteria; it was negatively correlated with the relative LH-PCR abundance and the biomass of Chlorobium sp. (PLFA and the proportion of total POC), as well as the methane concentration. The second PC explained $17.3 \%$ of the variability, and it clustered water column mixing days (19 September and 18 October) together on the direction of the $y$-axis. This axis was positively correlated with methanotrophic activity and heterotrophic bacterial production as well as with the relative LH-PCR abundance and the biomass of MOB (PLFA and proportion of total POC); thus, the second PC could be considered an MOB component.

\section{DISCUSSION}

The contributions of bacterial carbon to freshwater systems have been considered to rely mainly on heterotrophic processes. Here, we studied the seasonal role of heterotrophic, methanotrophic and photo- 
autotrophic bacteria in a boreal humic lake by using LH-PCR and PLFA methods with measurements of microbial activity. To integrate LH-PCR and PLFA results, they were weighted by the volume and POC to obtain relative abundance estimates for 3 seasons. Remarkably, the results indicated that Chlorobium sp. constituted over half of the open-water season POC biomass, and that MOB type I was another extremely important biomass former. Photoautotrophic bacteria already formed up to $28 \%$ of the biomass of the lake at the beginning of the season and later comprised, on average, $77 \%$ of the biomass during the summer, until the sudden drop during the autumn overturn. We found that photoautotrophic and methanotrophic bacteria may thus make a major contribution to the biomass and food web of this meromictic humic lake.

LH-PCR and PLFA methods were used to establish a new biomarker approach for a better understanding of seasonal changes and vertical biomass stratification. While the FA biomarkers provide an estimate of the biomass of the respective bacterial taxa, LH-PCR biomarkers provide an estimate of the relative abundance of the respective groups. Repeated measurements from the anaerobic water layers, where changes were slower, showed that the reproducibility of the LH-PCR method was good. The LH-PCR analysis in our study lake revealed that the 4 selected LH-PCR biomarkers covered, on average, $75 \%$ of the total LH-PCR intensity through the open-water season. A previous study had shown that some of the LH-PCR biomarkers were specific for certain bacterial genera (such as Chlorobium) in the study lake, whereas some included several bacterial groups (Taipale et al. 2009b). On the other hand, PLFA profiles of each bacterial taxon revealed some specific FAs; these could be used as biomarker PLFAs to monitor the seasonal dynamics of the bacterial groups. PLFA biomarkers for MOB have been used to monitor these organisms in different kinds of system (Borjesson et al. 1998, Mohanty et al. 2006, Kankaala et al. 2007b). It is also known that branched FAs are typical of Actinobacteria (Kaneda 1991) and could be used as biomarkers in the oxic epilimnion, although not in the anoxic hypolimnion because they are also typical FAs among some anaerobic bacteria (e.g. Bacteroides sp. and Desulfovibrio sp.) (Kaneda 1991). In this study, we identified new PLFA biomarkers for heterotrophic bacteria affiliated with the genus Polynucleobacter, as well as biomarkers for photoautotrophic bacteria affiliated with the genus Chlorobium. The carbon biomass of each of the 4 bacterial groups was calculated on the basis of these PLFA biomarkers, and the contribution of these groups to the total POC was estimated. Overall, our PLFA biomarker approach was mostly successful, but in some cases the calculated bacterial carbon biomass exceeded the measured POC values in the lower metalimnion and hypolimnion; this may indicate that the PLFA conversion factor overestimated the biomass of Chlorobium sp. For Polynucleobacter and Chlorobium, the characteristic biomarker concentrations were low and the PLFA conversion factor high, making the PLFA-based analysis more uncertain. As the MOB type I biomarkers we used were present in high concentrations in the MOB cells, the conversion factor for this group may yield more accurate results. Another explanation would be the difference in the nominal pore size of filters used for sample collection, which was $0.7 \mu \mathrm{m}$ for PLFA, $1.2 \mu \mathrm{m}$ for POC and $0.2 \mu \mathrm{m}$ for DNA. Thus, the POC measurements may have missed some smaller bacterial cells. Future applications of this approach should preferably use the same filter pore size to avoid possible discrepancies.

The calculated contributions of MOB and Chlorobium sp. based on LH-PCR and PLFA biomarkers were closely similar (see Table 3 and Fig 5B), although the former reflects cell numbers and the latter biomass. The LH-PCR method is based on the proportional numbers of cells (actually rRNA gene templates), whereas PLFA analysis is based on the biomass that depends on cell size. Nevertheless, there were some differences in the results for heterotrophic bacteria (Actinobacteria and Polynucleobacter spp.) between these 2 methods. The small size of planktonic Polynucleobacter spp. (see Hahn et al. 2004, 2009) can partly explain their high percentage abundance among the rRNA gene templates $(15 \%)$ compared to their low proportion of the PLFA biomarker-based biomass estimation $(3 \%)$, and the same can explain the difference in small-sized Actinobacteria. Furthermore, the PLFA approach may have underestimated the biomass of Polynucleobacter spp. and Actinobacteria due to the aforementioned filtration issues, resulting in an incomplete retention of the smallest bacteria in the PLFA samples. On the other hand, the LH-PCR biomarker for Polynucleobacter spp. was not affiliated exclusively to this genus, but included at least Methylophilus sp., whereas the PLFA biomarker may have been more specific for Polynucleobacter spp. In addition, some Polynucleobacter strains, such as Mekk-B1 and CBFaMC5 (S. Taipale et al. unpubl.) may have a lower specific concentration of the biomarker PLFA cy-19:0. Similarly, the LH-PCR approach may also have underestimated the relative abundance of Polynucleobacter spp. because genome sequencing has revealed that these bacteria, unlike many others, possess only 1 copy of the ribosomal operon (M. W. Hahn et al. unpubl. data). Altogether, differing results from these 2 methods applied in our study probably reflect both differences in the species-specific biomass-rRNA gene relationships and limitations of the methods. However, it 
can be noted that, by combining PLFA biomarkers with LH-PCR biomarkers, the role of these targeted groups of bacteria can be verified in different kinds of ecosystem in future studies.

Immediately after ice-melt, only $15 \%$ of the POC was of bacterial origin, whereas primary production and the phytoplankton biomass were high. During that time, Polynucleobacter spp. and Methylophilus sp. were the predominant bacterial groups in the oxic epilimnion (temporarily $\sim 60 \%$ of the relative LH-PCR intensity), but Chlorobium sp. still dominated the anaerobic water layers. Nevertheless, the biomass of Polynucleobacter spp. was low according to the PLFA analysis, which is logical when considering the extremely small size of Polynucleobacter spp. and the uncertainties related to the PLFA method.

Even though heterotrophic bacteria (including Methylophilus sp.) were relatively abundant in the entire water column during the open-water season, in the DNA-based analysis they contributed less than $5 \%$ of the POC biomass. Additionally, heterotrophic bacterial production, as measured by the uptake of ${ }^{14} \mathrm{C}$ leucine, was low in relation to primary production and the activities of GSB or MOB throughout the openwater season. According to $16 \mathrm{~S}$ rRNA gene sequencing (Taipale et al. 2009b), group 3a (cf. Alexander et al. 2002) was the dominant Chlorobium group during the summer stratification. A large biomass of these obligately anaerobic photoautotrophic bacteria persisted until the autumnal mixing of the water column, which caused a rapid drop in the population. A large biomass of photoautotrophic bacteria in Lake Mekkojärvi was first reported by Kuuppo-Leinikki \& Salonen (1992). In 5 small lakes, including our study lake, Lake Mekkojärvi, sampled in spring and autumn 2006, significant positive correlations were found between chlorophyll (dominated by bacteriochlorophyll $d$ ), total bacterial biomass (analyses by microscopy) and POC concentration (Kankaala et al. 2010). These results also indicate the importance of phototrophic bacteria in the carbon cycle of the oxygen-stratified boreal lakes. Substantial biomasses of photoautotrophic bacteria in anoxic water columns have also been reported from meromictic lakes (Gregersen et al. 2009), saline lakes (Lunina et al. 2005) and alpine lakes (Decristophoris et al. 2009). A large abundance of bacteria does not necessarily mean high rates of production, as the growth rate of members of the strictly anaerobic Chlorobi has been considered to be extremely low in environments with stable stratification (Parkin \& Brock 1980, Manske et al. 2005). However, we actually found a rapid increase in Chlorobium biomass in the re-stratifying metalimnion between the spring and summer sampling periods (about a 4-fold increase in $1 \mathrm{mo}$ ), indicating higher growth rates than previously assumed. Additionally, according to a comparison of the rate measurements in this and previous studies (Kuuppo-Leinikki \& Salonen 1992), rates of carbon fixation by both photoautotrophic and methanotrophic bacteria exceeded the primary production of phytoplankton during the summer period.

The water column turnover in autumn directly enhanced bacterial production, as measured by uptake of ${ }^{14} \mathrm{C}$-leucine, as well as the activity of the methanotrophic community. Evidently, during autumnal mixing, heterotrophic bacteria benefit from the upwelling nutrients and decaying cells of the substantial biomass (up to $3 \mathrm{mg} \mathrm{C}^{-1}$ ) of photoautotrophic bacteria. Our weekly monitoring of selected bacterial groups also revealed that the structure and biomass of the microbial community in the oxic epilimnion was not stable, but rapidly adapted to changes in the physicochemical environment, in contrast to the more stable anaerobic layers.

Our study showed that the abundance, biomass and production of the MOB were substantial during the entire open-water season, but especially during the autumn. Indeed, MOB was the only bacterial group found throughout the whole water column during the study period. All the analyses we used (MOB activity measurements, LH-PCR and PLFA biomarker studies) indicated that $\mathrm{MOB}$ was the dominant bacterial group during the autumn. During the autumnal mixing, MOB benefit from the co-availability of methane and oxygen in the whole water column (Kankaala et al. 2007b). During the stratification period, some methane oxidation was also measured from the anoxic water column, suggesting the occurrence of anaerobic methane oxidation (AOM). In the steeply stratified Plußsee (Germany), Eller et al. (2005) found a layer of anaerobic methane-oxidizing Archaea (ANME-I) below the zone of oxic MOB activity. Our study did not cover the Archaea, as the PCR protocol and PLFA analysis we used do not give information about that domain.

A previous inorganic ${ }^{13} \mathrm{C}$-tracer study revealed that phytoplankton is the most important carbon source for zooplankton during spring in this lake, but the proportion of different bacterial groups, especially MOB, in the diet of zooplankton increases in summer and in autumn (Taipale et al. 2008). The present study confirms the minor role of heterotrophic bacteria as allochthonous energy mobilisers in the lake and highlights the importance of alternative bacterial processes. Oligotrophic clear-water lakes usually have deep euphotic zones and an oxic water column which favours primary production over heterotrophic bacterial production. Lakes receiving more terrestrial organic carbon have shallower euphotic zones, due to the darker water colour, and oxygen is often depleted in the hypolimnia. Bacterial biomass has been reported 
to increase with water colour (Hessen 1985), and bacterial production can even exceed primary production in coloured lakes (Jansson et al. 2000). Our results show that most of the microbial biomass in the stratified polyhumic Lake Mekkojärvi comprised photoautotrophic bacteria and $\mathrm{MOB}$ during the summer stratification, and MOB during the autumn mixing. This indicates that, in polyhumic lakes with a thick anaerobic hypolimnion, the microbial link can actually be based mainly on photoautotrophic and methanotrophic production, exceeding the direct heterotrophic metabolism of allochthonous material.

Acknowledgements. This research was supported by Academy of Finland research grants 104438 and 105860 awarded to R.I.J. and 120089 awarded to M.T.

\section{LITERATURE CITED}

Alexander B, Andersen JH, Cox RP, Imhoff JF (2002) Phylogeny of green sulfur bacteria on the basis of gene sequences of 16S rRNA and of the Fenna-Matthews-Olson protein. Arch Microbiol 178:131-140

- Alonso C, Pernthaler J (2006) Concentration-dependent patterns of leucine incorporation by coastal picoplankton. Appl Environ Microbiol 72:2141-2147

> Arvola L, Salonen K, Kankaala P, Lehtovaara A (1992) Vertical distributions of bacteria and algae in a steeply stratified humic lake under high grazing pressure from Daphnia longispina. Hydrobiologia 229:253-269

Azam F, Fenchel T, Field JG, Gray JS, Meyer-Reil LA, Thingstad F (1983) The ecological role of water-column microbes in the sea. Mar Ecol Prog Ser 10:257-263

Bastviken D, Ejlertsson J, Sundh I, Tranvik L (2003) Methane as a source of carbon and energy for lake pelagic food webs. Ecology 84:969-981

Bligh EG, Dyer WJ (1959) A rapid method of total lipid extraction and purification. Can J Biochem Physiol 37:911-917

Borjesson G, Sundh I, Tunlid A, Svensson BH (1998) Methane oxidation in landfill cover soils, as revealed by potential oxidation measurements and phospholipid fatty acid analyses. Soil Biol Biochem 30:1423-1433

Boschker HTS, Middelburg JJ (2002) Stable isotopes and biomarkers in microbial ecology. FEMS Microbiol Ecol 40:85-95

Canfield DE, Kristensen E, Thamdrup B (2005) Aquatic geomicrobiology. Advances in Marine Biology 48. Elsevier Academic Press, San Diego, CA

> Carpenter SR, Cole JJ, Pace ML, Van de Bogert M and others (2005) Ecosystem subsidies: terrestrial support of aquatic food webs from 13C addition to contrasting lakes. Ecology 86:2737-2750

Decristophoris PMA, Peduzzi S, Ruggeri-Bernardi N, Hahn D, Tonolla M (2009) Fine scale analysis of shifts in bacterial community structure in the chemocline of meromictic Lake Cadagno, Switzerland. J Limnol 68:16-24

Eller G, Känel L, Krüger M (2005) Cooccurrence of aerobic and anaerobic methane oxidation in the water column of Lake Plußsee. Appl Environ Microbiol 71:8925-8928

> Fuhrman JA, Azam F (1980) Bacterioplankton secondary production estimates for coastal waters of Brittish Columbia, Antarctica, and California. Appl Environ Microbiol 39:1085-1095

Glöckner FO, Zaichikov E, Belkova N, Denissova L, Pern- thaler J, Pernthaler A, Amann R (2000) Comparative 16S rRNA analysis of lake bacterioplankton reveals globally distributed phylogenetic clusters including an abundant group of actinobacteria. Appl Environ Microbiol 66: 5053-5065

Gregersen LH, Habicht KS, Peduzzi S, Canfield DE, Miller M, Cox RP, Frigaard NU (2009) Dominance of a clonal green sulfur bacterial population in a stratified lake. FEMS Microbiol Ecol 70:30-41

Hadas O, Pinkas R, Erez J (2001) High chemoautotrophic primary production in Lake Kinneret, Israel: a neglected link in the carbon cycle of the lake. Limnol Oceanogr 46:1968-1976

> Hahn MW (2006) The microbial diversity of inland waters. Curr Opin Biotechnol 17:256-261

> Hahn MW (2009) Description of seven candidate species affiliated with the phylum Actinobacteria, representing planktonic freshwater bacteria. Int J Syst Evol Microbiol 59:112-117

> Hahn MW, Stadler P, Wu QL, Pöckl M (2004) The filtration-acclimatization method for isolation of an important fraction of the not readily cultivable bacteria. J Microbiol Methods 57:379-390

Hahn MW, Lang E, Brandt U, Wu QL, Scheuerl T (2009) Emended description of the genus Polynucleobacter and the species Polynucleobacter necessarius and proposal of two subspecies, $P$. necessarius subsp. necessarius subsp. nov. and $P$. necessarius subsp. asymbioticus subsp. nov. Int J Syst Evol Microbiol 59:2002-2009

> Heising S, Richter L, Ludwig W, Schink B (1999) Chlorobium ferrooxidans sp. nov., a phototrophic green sulfur bacterium that oxidizes ferrous iron in coculture with a 'Geospirillum' sp. strain. Arch Microbiol 172:116-124

$>$ Hessen DO (1985) The relation between bacterial carbon and dissolved humic compounds in oligotrophic lakes. FEMS Microbiol Ecol 31:215-223

Höfle MG, Haas H, Dominik K (1999) Seasonal dynamics of bacterioplankton community structure in a eutrophic lake as determined by 5S rRNA analysis. Appl Environ Microbiol 65:3164-3174

> Humborg C, Smedberg E, Blomqvist S, Mörth CM and others (2004) Nutrient variation in boreal and subarctic Swedish rivers: Landscape control of land-sea fluxes. Limnol Oceanogr 49:1871-1883

Imhoff JF (2003) Phylogenetic taxonomy of the family Chlorobiaceae on the basis of 16S rRNA and fmo (FennaMatthews-Olson protein) gene sequences. Int J Syst Evol Microbiol 53:941-951

Jansson M, Bergstrom AK, Blomqvist P, Drakare S (2000) Allochthonous organic carbon and phytoplankton/bacterioplankton production relationships in lakes. Ecology 81:3250-3255

Jones SE, Lennon JT (2009) Evidence for limited microbial transfer of methane in a planktonic food web. Aquat Microb Ecol 58:45-53

Kamjunke N, Tittel J (2008) Utilisation of leucine by several phytoplankton species. Limnologica 38:360-366

Kaneda T (1991) Iso- and anteiso-fatty acids in bacteria: biosynthesis, function, and taxonomical significance. Microbiol Rev 55:288-302

Kankaala P, Taipale S, Grey J, Sonninen E, Arvola L, Jones RI (2006) Experimental $\delta^{13} \mathrm{C}$ evidence for a contribution of methane to pelagic food webs in lakes. Limnol Oceanogr 51:2821-2827

Kankaala P, Eller G, Jones RI (2007a) Could bacterivorous zooplankton affect lake pelagic methanotrophic activity? Fundam Appl Limnol. Arch Hydrobiol 169:203-209 
Kankaala P, Taipale S, Nykänen H, Jones RI (2007b) Oxidation, efflux, and isotopic fractionation of methane during autumnal turnover in a polyhumic, boreal lake. J Geophys Res 112, G02003, doi:10.1029/2006JG000336

Kankaala P, Taipale S, Li L, Jones RI (2010) Diets of crustacean zooplankton, inferred from stable carbon and nitrogen isotope analyses, in lakes with varying allochthonous dissolved organic carbon content. Aquat Ecol 44:781-795

Keskitalo J, Salonen K (1994) Manual for integrated monitoring, subprogramme hydrobiology of lakes. Publications of the Water and Environment Administration 16:1-41

King GM (1992). Ecological aspects of methane oxidation, a key determination of global methane dynamics. In: Marshall KC (ed) Advances in microbial ecology. Plenum Press, New York, NY, p 431-468

Kirchman D, K'nees E, Hodson R (1985) Leucine incorporation and its potential as a measure of protein synthesis by bacteria in natural aquatic systems. Appl Environ Microbiol 49:599-607

Kortelainen P (1993) Content of total organic carbon in Finnish lakes and its relationship to catchment characteristics. Can J Fish Aquat Sci 50:1477-1483

Kritzberg ES, Cole JJ, Pace ML, Granéli W (2006a) Bacterial growth on allochthonous carbon in humic and nutrientenriched lakes: results from whole-lake 13C addition experiment. Ecosystems 9:489-490

Kritzberg ES, Langenheder S, Lindström ES (2006b) Influence of dissolved organic matter source on lake bacterioplankton structure and function implications for seasonal dynamics of community composition. FEMS Microbiol Ecol 56:406-417

Kuuppo-Leinikki P, Salonen K (1992) Bacterioplankton in a small polyhumic lake with an anoxic hypolimnion. Hydrobiologia 229:159-168

Lindström ES (2000) Bacterioplankton community composition in five lakes differing in trophic status and humic content. Microb Ecol 40:104-113

Lindström ES, Forslund M, Algesten G, Bergström AK (2006) External control of bacterial community structure in lakes. Limnol Oceanogr 51:339-342

Lunina ON, Gorlenko VM, Solov'eva OA, Akimov VN, Rusanov II, Pimenov NV (2005) Seasonal changes in the structure of the anoxygenic phototrophic bacterial community in Lake Mogilnoe, a relict lake on Kil'din Island in the Barents sea. Microbiology 74:588-596

Manske AK, Glaeser J, Kuypers MM, Overmann J (2005) Physiology and phylogeny of green sulfur bacteria forming a monospecific phototrophic assemblage at a depth of 100 meters in the Black Sea. Appl Environ Microbiol 71:8049-8060

Mills DK, Fitzgerald K, Litchfield CD, Gillevet PM (2003) A comparison of DNA profling techniques for monitoring nutrient impact on microbial community composition during bioremediation of petroleum-contaminated soils. J Microbiol Methods 54:57-74

Mohanty SR, Bodelier PLE, Floris V, Conrad R (2006) Differential effects of nitrogenous fertilizers on methaneconsuming microbes in rice field and forest soils. Appl Environ Microbiol 72:1346-1354

Münster U, Heikkinen E, Likolammi M, Järvinen M, Salonen K, Haan HD (1999) Utilisation of polymeric and monomeric aromatic and amino acid carbon in a humic boreal forest lake. Arch Hydrobiol Adv Limnol (Spec Iss) 54:105-134

> Parkin TB, Brock TD (1980) Photosynthetic bacterial production in lakes: the effects of light intensity. Limnol
Oceanogr 25:711-718

Percent SF, Frischer ME, Vescio PA, Duffy EB and others (2008) Bacterial community structure of acid-impacted lakes: What controls diversity? Appl Environ Microbiol 74:1856-1868

Pernthaler J, Glöckner FO, Unterholzner S, Alfreider A, Psenner R, Amann R (1998) Seasonal community and population dynamics of pelagic bacteria and Archaea in a high mountain lake. Appl Environ Microbiol 64:4299-4306

Pfennig N (1968) Chlorobium phaeobacteroides nov. spec. und C. phaeovibrioides nov. spec. Zwei neue Arten der grünen Schwefelbakterien. Arch Mikrobiol 63:224-226

Ratledge C, Wilkinson SG (1988) Microbial lipids. Academic Press, London

Salonen K (1979) A versatile method for the rapid and accurate determination of carbon by high temperature combustion. Limnol Oceanogr 24:177-183

Sundh I, Bastviken D, Tranvik LJ (2005) Abundance, activity, and community structure of pelagic methane-oxidizing bacteria in temperate lakes. Appl Environ Microbiol 71:6746-6752

Suzuki M, Rappe MS, Giovannoni SJ (1998) Kinetic bias in estimates of coastal picoplankton community structure obtained by measurements of small-subunit rRNA gene PCR amplicon length heterogeneity. Appl Environ Microbiol 64:4522-4529

> Taipale S, Kankaala P, Jones RI (2007) Contributions of different organic carbon sources to Daphnia in the pelagic foodweb of a small polyhumic lake: results from mesocosm (DIC)-C-13-additions. Ecosystems 10:757-772

Taipale S, Kankaala P, Tiirola M, Jones RI (2008) Whole-lake dissolved inorganic ${ }^{13} \mathrm{C}$ additions reveal seasonal shifts in zooplankton diet. Ecology 89:463-474

Taipale S, Kankaala P, Hämäläinen H, Jones RI (2009a) Seasonal shifts in the diet of lake zooplankton revealed by phospholipid fatty acid analysis. Freshw Biol 54:90-104

Taipale S, Jones RI, Tiirola M (2009b) Vertical diversity of bacteria in an oxygen-stratified humic lake, evaluated using DNA and phospholipid analyses. Aquat Microb Ecol 55:1-16

- Takahashi M, Ichimura S (1970) Photosynthetic properties and growth of photosynthetic sulphur bacteria in lakes. Limnol Oceanogr 15:929-944

Templeton AS, Chu KH, Alvarez-Cohen L, Conrad ME (2006) Variable carbon isotope fractionation expressed by aerobic $\mathrm{CH}_{4}$ oxidizing bacteria. Geochim Cosmochim Acta 70:1739-1752

> Tiirola MA, Suvilampi JE, Kulomaa MS, Rintala JA (2003) Microbial diversity in a thermophilic aerobic biofilm process: analysis by length heterogeneity PCR (LH-PCR). Water Res 37:2259-2268

Tulonen T (1993) Bacterial production in a mesohumic lake estimated from $\left[{ }^{14} \mathrm{C}\right]$ leucine incorporation rate. Microb Ecol 26:201-217

> Wartiainen I, Hestnes AG, McDonald IR, Svenning MM (2006) Methylobacter tundripaludum sp. nov., a methaneoxidizing bacterium from Arctic wetland soil on the Svalbard islands, Norway $\left(78^{\circ} \mathrm{N}\right)$. Int J Syst Evol Microbiol 56:109-113

Weisse T (2004) Pelagic microbes-protozoa and the microbial food web. In: O'Sullivan PE, Reynolds CS (eds) The lakes handbook, vol 1-Limnology and limnetic ecology. Blackwell, Oxford, p 417-460

> Zwart G, Crump BC, Kamst-van Agterveld MP, Hagen F, Han SK (2002) Typical freshwater bacteria: an analysis of available 16S rRNA gene sequences from plankton of lakes and rivers. Aquat Microb Ecol 28:141-155 
Appendix 1. Phospholipid fatty acid (PLFA) profiles (\% area) of cultured bacterial strains

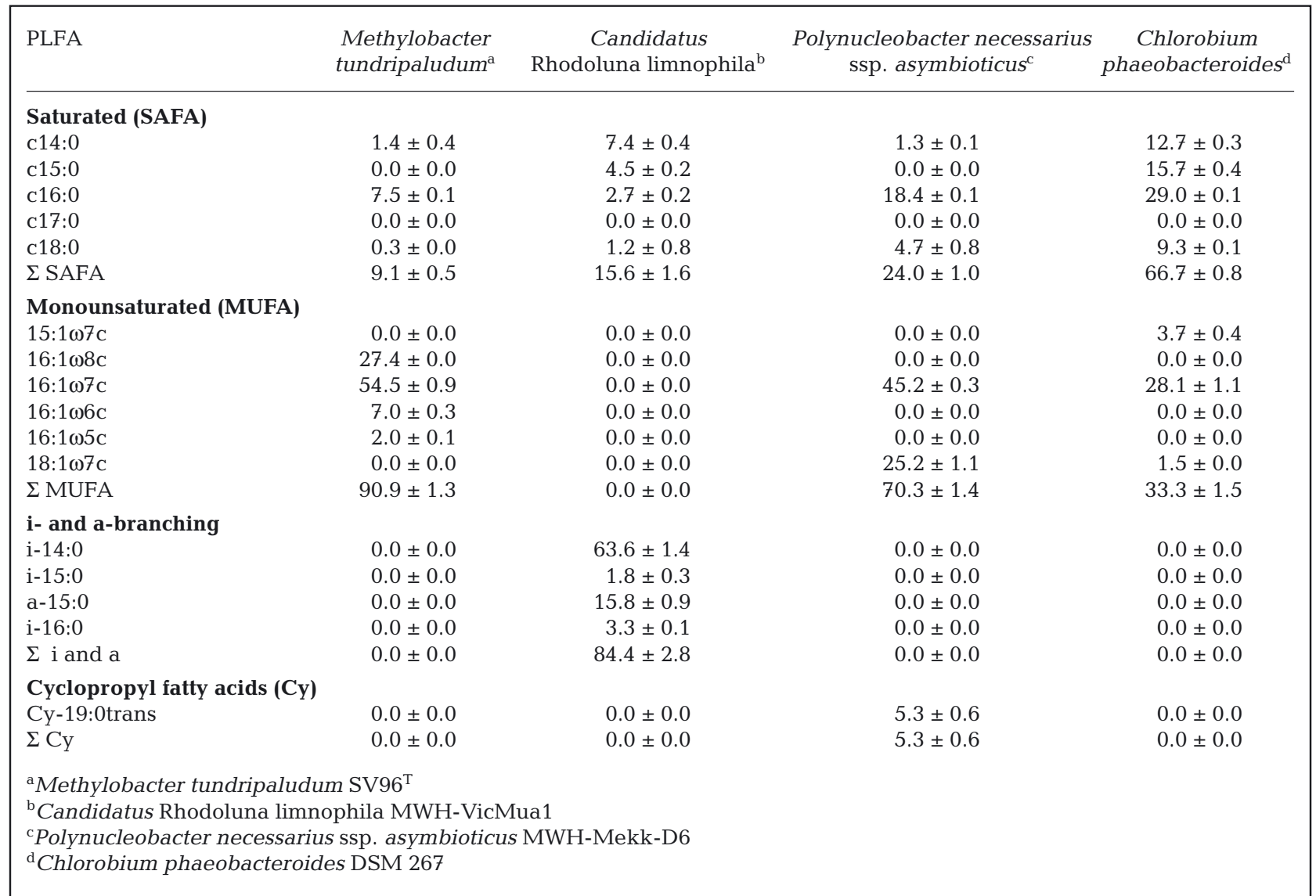

Editorial responsibility: Karel Šimek, České Budějovice, Czech Republic
Submitted: November 18, 2010; Accepted: April 11, 2011 Proofs received from author(s): July 11, 2011 